\title{
Influence of tectonic folding on rockfall susceptibility, American Fork Canyon, Utah, USA
}

\author{
J. A. Coe and E. L. Harp \\ U.S. Geological Survey, Denver Federal Center, MS 966, Denver, CO, 80225, USA
}

Received: 23 May 2006 - Revised: 12 December 2006 - Accepted: 13 December 2006 - Published: 10 January 2007

\begin{abstract}
We examine rockfall susceptibility of folded strata in the Sevier fold-thrust belt exposed in American Fork Canyon in north-central Utah. Large-scale geologic mapping, talus production data, rock-mass-quality measurements, and historical rockfall data indicate that rockfall susceptibility is correlated with limb dip and curvature of the folded, cliff-forming Mississippian limestones. On fold limbs, rockfall susceptibility increases as dip increases. This relation is controlled by several factors, including an increase in adverse dip conditions and apertures of discontinuities, and shearing by flexural slip during folding that has reduced the friction angles of discontinuities by smoothing surface asperities. Susceptibility is greater in fold hinge zones than on adjacent limbs primarily because there are greater numbers of discontinuities in hinge zones. We speculate that susceptibility increases in hinge zones as fold curvature becomes tighter.
\end{abstract}

\section{Introduction}

Rockfall affects mountainous regions throughout the world (Whalley, 1984). At regional scales, susceptibility to rockfall can be affected by variations in climate (Hales and Roering, 2005), topography (Miller and Dunne, 1996), and rock characteristics (Allison and Kimber, 1998). At local scales, where climate and topography are similar, variability in rockfall susceptibility is due to differences in rock characteristics, the local stress state, and variations in surface and subsurface water. The presence of discontinuities (fractures, bedding planes, lithologic boundaries, schistosity) in rock imposes an anisotropic strength that can dramatically affect the mechanisms and frequency of rock failures (Hencher, 1987; Weissel and Seidl, 1997). The strength and deformability of rock masses are often more dependent on the nature of discontinuities than on the lithologic properties of intact rock (e.g., Selby, 1982; Norrish and Wyllie, 1996; Hantz et al., 2003;

Correspondence to: J. A. Coe

(jcoe@usgs.gov)
Jaboyedoff et al., 2004). Discontinuities also affect the flow of water (Freeze and Cherry, 1979), which can adversely impact slope stability (Pierre and Lahousse, 2006).

Tectonic folding increases the density and interconnectedness of discontinuities in rock masses as a function of fold geometry (Lisle, 1994), stratigraphy (Cooke, 1997), and the presence or absence of preexisting discontinuities (Bergbauer and Pollard, 2004). Given these observations, a correspondence between fold characteristics and rockfall susceptibility might be expected. In this paper, we examine the rockfall susceptibility of variably folded Mississippian limestones in a $1.1 \mathrm{~km}^{2}$ study area in American Fork Canyon, Utah (Fig. 1). We use the data of Coe et al. (2005) to better understand the effect that folding has on rockfall susceptibility.

\section{Study area}

American Fork Canyon is a deeply-incised canyon that transects the Wasatch Range in north-central Utah (Fig. 1). The lower part of the canyon, including the reach containing the study area, is V-shaped and has been incised by the American Fork River. The western flank of the Wasatch Range forms the eastern boundary of the Basin and Range province of western North America. The Wasatch Range is being actively exhumed by movement along the Wasatch Fault. Estimates of exhumation rates range from 0.05 to $0.8 \mathrm{~mm} / \mathrm{yr}$ (Ehlers et al., 2003). Because of ongoing exhumation and incision, the area is characterized by high relief; relief from the mouth of American Fork Canyon to the top of Mount Timpanogos (Fig. 1) is about $2000 \mathrm{~m}$. Rockfall is the most common type of mass movement in American Fork Canyon. McNeil et al. (2002) documented rockfall activity in Timpanogos Cave National Monument about $3 \mathrm{~km}$ west of the study area.

Incision by the American Fork River has exposed a series of folds and faults within the Sevier fold-thrust belt, an eastverging zone of thin-skinned crustal shortening formed during Late Jurassic and early Tertiary time (Armstrong, 1968;

Published by Copernicus GmbH on behalf of the European Geosciences Union. 


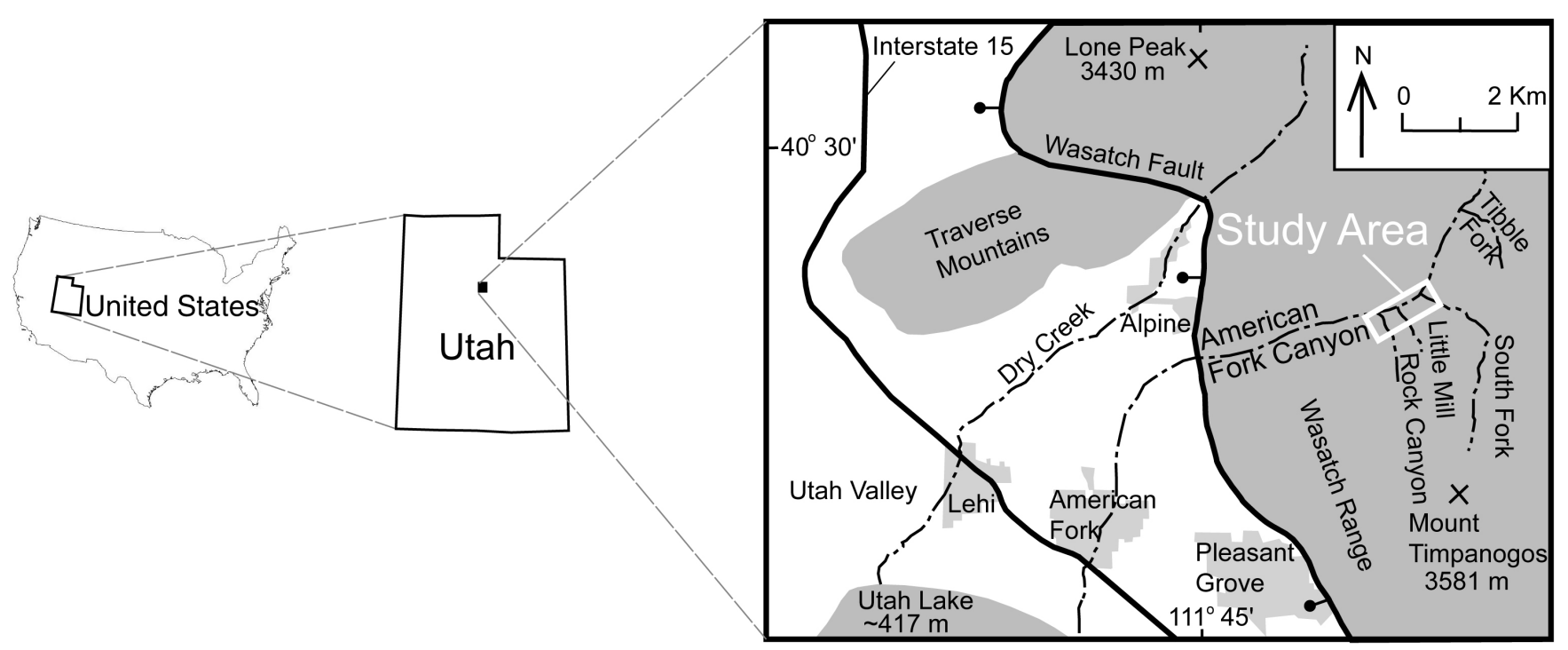

Fig. 1. Map showing the location of the study area.

Paulsen and Marshak, 1998). Within the study area, concentric and non-concentric, shallowly plunging folds are present. Fold axes are near normal to the canyon walls; axial plane traces trend between $\mathrm{N} 30 \mathrm{~W}$ and $\mathrm{N} 35 \mathrm{~W}$. The orientation of the fold axes with respect to the canyon has created crosssectional exposures of fold limbs and hinge zones; an ideal situation for studying the relation between fold geometry and rockfall susceptibility. The folds deform a thick sequence of Mississippian-age limestones (Baker and Crittenden, 1961), the Gardison Limestone, Deseret Limestone, and Humbug Formation. These limestone units are similar lithologically, but each has wide variations in bedding thickness.

\section{Methods}

To evaluate the effect that fold structure has on rockfall susceptibility, we used an approach that included large-scale geologic mapping, estimates of talus production, rock-massquality measurements, and a compilation of historical rockfall data. Geologic units mapped included the position of undifferentiated limestone on fold limbs or in fold hinge zones, and surficial deposits (Fig. 2). Each map unit is described in detail in Table 1. The first five units listed in Table 1 are limestone bedrock units with various fold positions, and the last six units are surficial deposits. Field observations and mapping were conducted as an iterative process. Initial observations included identifying source areas for recent rockfalls, recording the bedding dip and fold positions of rocks in source areas, noting the relative age of talus deposits, and identifying the location, type, and freshness of rockfall scars on trees and asphalt surfaces. After these initial observations were made, we produced a 1:3000-scale map using 1:6000-scale stereographic aerial photographs and a PG-
2 photogrammetric plotter (Pillmore, 1989). The map was checked for completeness and accuracy during subsequent field work. Folds shown on the map are classified in terms of interlimb angle (Fig. 3, from Fleuty, 1964) as follows: gentle folds, $180-120^{\circ}$; open folds, $120-70^{\circ}$; close folds, $70-30^{\circ}$; tight folds, $30-0^{\circ}$, and isoclinal folds, $0^{\circ}$.

To quantify field observations regarding variable talus production from different bedrock fold positions, we computed a Talus Production Ratio (TPR, see Table 2) for the five types of fold positions described in Table 1 and shown in Fig. 2. We computed TPR by dividing the total area of young talus (unit Yt in Table 1 and Fig. 2) located downslope from each type of fold position, by the total area of bedrock for each fold position. For example, to compute a TPR for shallowdipping limbs (unit Shdl), we divided the total area of Yt that was located downslope from Shdl, by the total area of Shdl (see Table 2). All area values were determined using Fig. 2 in a Geographic Information System. We used young talus (Yt), instead of older talus (Ot, Table 1 and Fig. 2), to compute TPR because it best represents recent and ongoing rates of rockfall activity (compare descriptions of $\mathrm{Yt}$ and $\mathrm{Ot}$ in Table 1).

To assess the relative rockfall susceptibility of cliffs in the study area we used a rock-mass classification scheme known as Rock Mass Quality (Barton et al., 1974; Harp and Noble, 1993). This empirical classification scheme uses the characteristics of rock discontinuities to quantify the potential for rockfall initiation. Rock Mass Quality $(\mathrm{Q})$ is calculated using numerical ratings for six discontinuity characteristics measured in a cubic meter of rock at field sites:

$Q=\left[\frac{115-3.3 J v}{J n}\right]\left[\frac{J r}{J a}\right]\left[\frac{J w}{A F}\right]$, 
Table 1. Description of geologic units shown in Fig. 2.

\begin{tabular}{|c|c|}
\hline Geologic Unit & Description \\
\hline Shdl, Shallow-dipping limestone & Limestone bedrock with bedding plane dips of about $20^{\circ}$ or less. \\
\hline Mdl, Moderately-dipping limestone & Limestone bedrock with bedding plane dips between about $20^{\circ}$ and $40^{\circ}$. \\
\hline Stdl, Steeply-dipping limestone & Limestone bedrock with bedding plane dips that exceed about $40^{\circ}$ \\
\hline Gfhz, Hinge zone of gentle fold & $\begin{array}{l}\text { Limestone bedrock adjacent to the fold axial plane of folds with inter- } \\
\text { limb angles between } 180-120 \text { degrees. }\end{array}$ \\
\hline Fhz, Faulted hinge zone & $\begin{array}{l}\text { Limestone bedrock adjacent to the fold axial plane of folds where the } \\
\text { axial plane has been cut by a fault. }\end{array}$ \\
\hline Yt, Young talus deposits & $\begin{array}{l}\text { Steeply sloping, loose accumulations of fragmented, angular rocks } \\
\text { ranging in size from pebbles to boulders. Talus deposits are located } \\
\text { between bedrock cliffs and the toe of the slope. These deposits are } \\
\text { differentiated from older talus deposits by a general lack of mature veg- } \\
\text { etation and the presence of extensive, freshly exposed surfaces on rock } \\
\text { fragments. }\end{array}$ \\
\hline Ot, Older talus, colluvium, and soil & $\begin{array}{l}\text { A steeply-sloping deposit containing a mixture of rock fragments and } \\
\text { finer-grained soil material. These deposits occupy slope positions both } \\
\text { downslope and upslope from bedrock cliffs and are differentiated from } \\
\text { younger talus deposits by the widespread presence of mature vegetation. }\end{array}$ \\
\hline Df, Debris-flow fans & $\begin{array}{l}\text { Fan-shaped deposits at the mouths of ephemeral tributary drainages to } \\
\text { the American Fork River that were primarily deposited by debris flows } \\
\text { and water-dominated flows. Fans are usually covered by widespread, } \\
\text { mature vegetation. }\end{array}$ \\
\hline Dc, Debris cones & $\begin{array}{l}\text { Steep, cone-shaped deposits at the base of steep and small ephemeral } \\
\text { tributary gulleys to the American Fork River. Debris cones are smaller } \\
\text { and steeper than debris fans and have likely been deposited by multiple } \\
\text { processes including snow avalanches, rockfalls, water-dominated flows, } \\
\text { and debris flows (Selby, 1993). Cones are usually covered by vegeta- } \\
\text { tion. This definition departs from the American Geological Institute's } \\
\text { (AGI) definition of debris cone (Bates and Jackson, 1987). AGI defines } \\
\text { the term as an alluvial fan with very steep slopes, composed of thicker } \\
\text { and coarser material believed to have been deposited by larger streams } \\
\text { than those that form alluvial fans with less steep slopes. }\end{array}$ \\
\hline Al, Alluvium & $\begin{array}{l}\text { Stream-channel and flood-plain sediment along the canyon bottom de- } \\
\text { posited by the American Fork River. Sediment includes clay, silt, sand, } \\
\text { and rounded-to-subrounded pebble- to boulder-sized clasts. Locally in- } \\
\text { cludes angular rocks that range up to boulder size that were derived } \\
\text { from rockfalls from limestone cliffs adjacent to the river. }\end{array}$ \\
\hline Ml, Modified land & Primarily fill material beneath Highway 92. \\
\hline
\end{tabular}

where $J v$ is the total number of discontinuities, $J r$ describes the roughness of the surface of the discontinuities, $J n$ is the number of sets of discontinuities, $J a$ describes the type of filling or alteration on the surface of discontinuities, $J w$ is the water reduction factor, and $A F$ describes the aperture or "openness" of discontinuities. The AF factor is significantly affected by the presence of discontinuities with adverse dip (discontinuities dipping in the same direction as the topographic slope, see Harp and Noble, 1993). The expression $115-3.3 J v$ is also known as Rock Quality Designation (RQD, Deere and Deere, 1989). Numerical ratings for each of these factors are assigned based on a correlation of field measurements with descriptive rankings (see Fig. 4). Values of $\mathrm{Q}$ are inversely related to rockfall susceptibility.
Each quotient in Eq. (1) was used to estimate other rock properties at each field site. The first quotient, $R Q D / J n$, approximates the relative block size within the mass (Barton et al., 1974). The second quotient, $J r / J a$, expressed as $\tan ^{-1}(\mathrm{Jr} / \mathrm{Ja})$, approximates the inter-block friction angle that might be expected for various combinations of discontinuity roughness and alteration products. The third quotient, $J w / A F$, which is $1 / A F$ in our application because the rocks were dry when measurements were made, was used to estimate the relative "tightness" of the rock at each site (i.e., smaller apertures yield "tighter" rock).

To analyze $\mathrm{Q}$ data, as well as the six continuity characteristics in Eq. (1), we used basic descriptive statistics and the Mann-Whitney U-Test (Mann Whitney, 1947; Wilcoxon, 
Table 2. Quantitative results from mapping and compilation of historical rockfalls. Number of historical rockfalls for steeply-dipping limbs and the faulted-hinge zone are a minimum estimate of individual falls contained in a grouped historical record (see rockfall number 1 in Table 3 of Coe et al. (2005). U.S. Forest Service personnel indicate that the faulted-hinge zone and adjacent steeply-dipping limbs are the most active rockfall sites in the study area.

\begin{tabular}{|c|c|c|c|c|c|}
\hline Map Unit (Fold Position) & $\begin{array}{l}\text { Total Area of } \\
\text { exposed bedrock } \\
\text { (hectares) }\end{array}$ & $\begin{array}{l}\text { Total Area } \\
\text { of downslope } \\
\text { young talus } \\
\text { (hectares) }\end{array}$ & $\begin{array}{l}\text { Number of his- } \\
\text { torical rockfalls }\end{array}$ & $\begin{array}{l}\text { Talus Production } \\
\text { Ratio } \\
\text { (TPR, talus } \\
\text { area/bedrock } \\
\text { area) }\end{array}$ & $\begin{array}{l}\text { Rockfall Produc- } \\
\text { tion Ratio } \\
\text { (RPR, number of } \\
\text { rockfalls/bedrock } \\
\text { area (number per } \\
\text { hectare)) }\end{array}$ \\
\hline Shdl, Shallow-dipping limbs & 10.31 & 1.84 & 1 & 0.18 & 0.10 \\
\hline Gfhz, Hinge zones of gentle folds & 6.64 & 1.17 & 5 & 0.18 & 0.75 \\
\hline Fhz, Faulted hinge zone & 3.86 & 2.33 & 2 & 0.61 & 0.52 \\
\hline
\end{tabular}

1945). The Mann-Whitney U-Test is a non-parametric test of significance used to determine if differences (specifically, differences in the medians) between two groups of samples are significant, or whether the differences could have occurred by chance. The Mann-Whitney test is used in place of a parametric t-test when the number of samples is small (i.e., less than 20), data are measured on an ordinal (i.e., an ordered sequence) scale, and it is unclear if the population from which the samples were drawn is normally distributed. Our sample data meet these criteria.

We use the Mann-Whitney test to compare sample data from different fold positions (for example, data from shallow and steep fold limbs). The null hypothesis of the test is that the two groups of sample data are drawn from a single population and therefore the medians are equal. Probability values ( $p$ values) from the Mann-Whitney test indicate the probability that the two medians being compared would be truly different if the entire population was examined. For example, a $\mathrm{p}$ value of $0.05(5 \%)$ indicates that there is a $95 \%$ chance that the two medians are different. By convention, the typical critical value of $\mathrm{p}$ used to determine significance is 0.05 (i.e., the null hypothesis is rejected for $\mathrm{p}$ values less than 0.05). However, because our number of samples is small (groups ranging from 8 to 13 samples) and the Mann-Whitney test can be statistically less powerful (sensitive) than the parametric t-test, we use a critical value of 0.10 in this study.

We compiled information on historical rockfalls in the study area using newspaper articles, eyewitness accounts, personal observations, and published reports (see Coe et al., 2005). We searched the on-line archive of the Deseret News newspaper for articles that described rockfalls using the keywords "rock fall", "rockfall", "rock slide", "rockslide", "falling rock", "American Fork Canyon", "Little Mill campground", "Highway 92", and "U-92". The on-line archive included articles from 1988 to present. Eyewitness accounts were provided by U.S. Forest Service employees working in the area. Personal observations were made by the authors in October and November, 2004.

The compiled historical rockfall record has several limitations. First, the record is incomplete because we observed evidence of recent rockfalls (scarred trees and pavement) that have not been recorded in any personal account, newspaper, or report. Second, the record contains little or no data on rockfall detachment mechanisms, rockfall disintegration along travel paths, or specific rockfall trajectories. Lastly, some of the data from individual rockfalls in one area (i.e., the faulted hinge zone and steeply dipping limbs, Fhz and Stdl, Fig. 2) have been grouped together as single records. Thus, exact determinations of numbers of individual rockfalls and times of occurrence in this area were difficult.

Even though the historical record has limitations, it was still useful for our study, especially when combined with the geologic map data shown in Fig. 2. To quantify historical rockfall production from different bedrock fold positions, we computed a Rockfall Production Ratio (RPR, see Table 2) for the five types of fold positions described in Table 1 and shown in Fig. 2. We computed RPR by dividing the total number of historical rockfalls that initiated from bedrock in each fold position, by the total area of bedrock for each fold position. For example, to compute a RPR for shallowdipping limbs (unit Shdl), we divided the total number of rockfalls that initiated from Shdl by the total area of Shdl. As with TPR, all area values were determined using Fig. 2 in a Geographic Information System.

\section{Results}

Geologic mapping and field observations contributed a considerable amount to our understanding of rockfall in the 


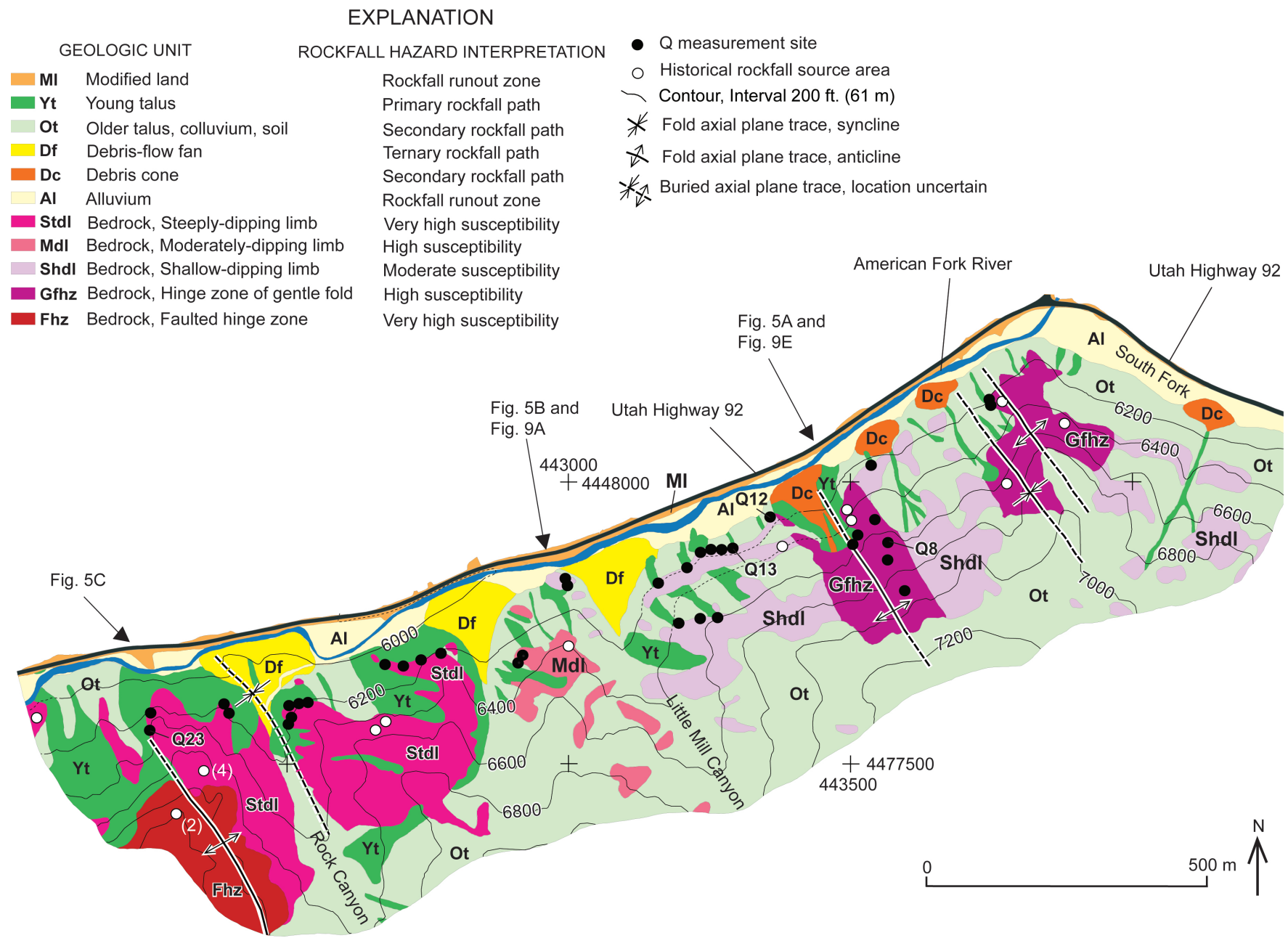

Fig. 2. Geologic map of the study area. Coordinates and tick marks are Universal Transverse Mercator, zone $12 \mathrm{~N}$, meters. Fold limbs are defined as follows: shallow dipping, $0-20^{\circ}$; moderately dipping, $20-40^{\circ}$; steeply-dipping, $>40^{\circ}$. Historical rockfalls are approximately located. Numbers by two rockfalls refer to minimum quantities of falls at those locations.

study area. Figure 2 shows the location of limestone bedrock mapped as a function of fold position, fresh and older talus deposits, debris fans, debris cones, and alluvium deposited by the American Fork River. Each unit shown in Fig. 2 is further defined in Table 1. Field observations indicated that fold geometries ranged from gentle folds with shallowly dipping limbs (Fig. 5a), to close folds with steeply-dipping limbs (Fig. 5c). Three folds are gentle (Fig. 5a), one is a close fold (buried hinge, Fig. 5c), and one is an apparent close fold that has been faulted (Fig. 5c). The folds are Ramsey Class 1B and $1 \mathrm{C}$, with curved-style hinge zones, and appear to have formed by flexural slip (Ramsey, 1967).

Mapped areas of steeply-dipping limbs and the faulted hinge zone have greater accumulations of fresh, downslope talus than do shallow-dipping limbs (Fig. 2). TPR increases systematically from shallow-dipping fold limbs to steeplydipping fold limbs (Table 2). A similar increase is seen as progressing from hinge zones of gentle folds to the faultedhinge zone, but there is no difference in TPR between hinge zones of gentle folds and shallow dipping limbs (Table 2).

Rock Mass Quality (Q) values at 36 sites (Fig. 2) ranged from 0.11 to 16.96 (Figs. 6 and 7). This large range reflects the heterogeneity of the rock mass in the study area, which can be highly variable over short distances, even within individual map units (for example, see Fig. 7d). This heterogeneity is the primary reason we chose to use multiple methods (i.e., Q, talus production, and historical rockfalls), rather than $\mathrm{Q}$ alone, to assess the relations between fold geometry and rockfall susceptibility. The logic is that, although Q measurements might be locally affected by this heterogeneity, the other two methods should average, or smooth out, the variation in rockfall susceptibility due to local heterogeneities within the rock mass. A previous assessment of $\mathrm{Q}$ measurements from a different geographic area is helpful 


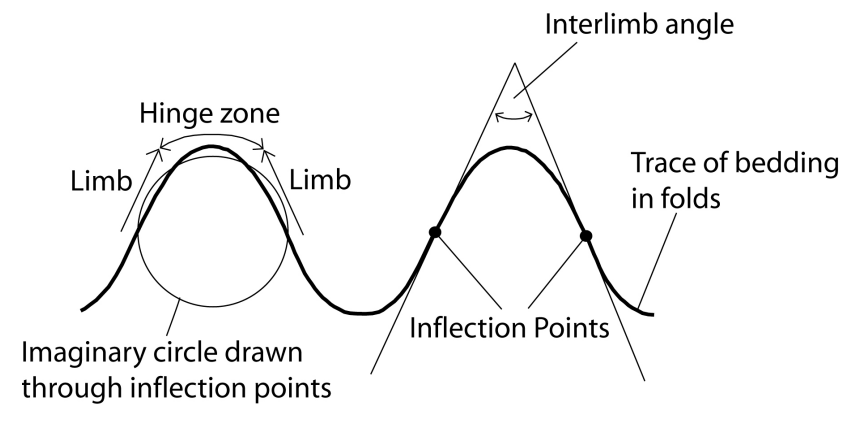

Fig. 3. Diagram showing cross-section view of fold hinge zone, limbs, and interlimb angle. Interlimb angle is the angle formed between lines tangent to the inflection points. Modified after Price and Cosgrove (1990) and Fleuty (1964).

to classify and interpret Q values in our study area. Harp and Jibson (2002) classified rockfall susceptibility based on $\mathrm{Q}$ values as follows: $0.001-0.1$, very high; $0.1-1$, high; $1-$ 10, moderate; and 10-100, low. According to this classification scheme, 58 percent of our measurement sites have high susceptibility, 39 percent have moderate susceptibility, and 3 percent have low susceptibility.

A Mann-Whitney analysis of $Q$ data from fold limbs indicates a significant $(\mathrm{p}=0.08)$, inverse relation between $\mathrm{Q}$ and steepness of limb dip (Fig. 8a). Said another way, rockfall susceptibility is greater on steeply dipping limbs than on shallow dipping limbs, which is in agreement with TPR results (Table 2) that show talus production increasing as limb dip increases. Additional analyses of discontinuity characteristics from Eq. (1) reveal that median values of relative inter-block friction angle $\left(\tan ^{-1}(J r / J a)\right)$, rock tightness $(1 / A F)$, and roughness of discontinuities $(J r)$, are significantly less on steeply dipping limbs than on shallow dipping limbs (Figs. 8c-e). Of these three characteristics, the difference in the medians of $J r$ is the most dramatic ( $\mathrm{p}=0.01$, Fig. 8e), indicating that the surfaces of discontinuities are dramatically smoother on steep limbs than on shallow limbs. Median values of relative block size $(R Q D / J n)$ and abundance of discontinuities $(J v)$ are not different at the 0.10 significance level (Figs. 8b and f).

A Mann-Whitney comparison of $Q$ data and discontinuity characteristics from the hinge-zones of gentle folds shown in Fig. 5a, with data from the shallow-dipping limbs adjacent to these hinges, reveals that none of the median values are different at the 0.10 significance level (Figs. $8 \mathrm{~g}-1$ ). This result seemingly indicates that rockfall susceptibility does not vary significantly between hinge zones of gentle folds and shallow-dipping limbs, which is in agreement with TPR results showing no difference in talus production between the two fold positions (Table 2). However, we examined these results further by an additional analysis of the abundance of discontinuities $(J v)$, the only characteristic from Eq. (1) that is based on a ratio scale (a count, see Fig. 4) rather than an ordinal scale. Because $J v$ is measured on a ratio scale, and its distribution approximates normal (Fig. 6), we were able to analyze $J v$ data shown in Fig. 81 using a more statistically sensitive parametric t-test. Results from this analysis indicated that the mean values of $J v$ from the hinges and shallow limbs were different $(\mathrm{p}=0.05)$ at the 0.10 significance level. This result indicates that the number of discontinuities is significantly greater in hinge zones than on adjacent limbs.

We compiled information on 16 historical rockfalls in the study area (see Fig. 9 for examples or Table 3 in Coe et al., 2005, for complete listing). Fourteen of these falls initiated from hinge zones and steeply-dipping limbs (Table 2). All rockfalls were observed and recorded during a 13 year period between 1992 and 2005. Therefore, on average, there was about 1 rockfall per year recorded in the study area. The size of falling rocks was highly variable; maximum rock dimensions range from several $\mathrm{cm}$ up to about $3.5 \mathrm{~m}$. Rockfalls occurred during winter, after heavy snowfall, during spring snowmelt, and during or immediately after prolonged rainfall (controls similar to those observed by Wieczorek and Snyder, 2004, for rockfalls in Yosemite National Park). Eyewitness information on the types of initial movement (e.g., falling, sliding, or toppling, Varnes, 1978) associated with historical rockfalls is non-existent. Field observations of potential rockfall source areas and recent rockfall initiation sites suggest that all types of movements occur, but that falls and topples are often preceded by at least minor amounts of sliding.

The Rockfall Production Ratio (RPR) computed on the basis of historical rockfall records, increases systematically with the dip of fold limbs (Table 2), which is consistent with results from our analysis of Q and TPR. The RPR from steeply dipping limbs is about 6 times greater than the RPR from shallow-dipping limbs (Table 2). The RPR from hinge zones of gentle folds is about 1.7 times larger than from steeply dipping limbs and about 7.5 times larger than from shallow dipping limbs. This result suggests that hinge zones of gentle folds have much higher rockfall susceptibility than shallow dipping limbs, which is a different conclusion than suggested by our TPR results. The reason for this difference is unclear, but it seems to indicate that there may be a difference between long-term talus production and historical rockfall activity, at least in hinge zones of gentle folds, in the study area. Additionally, unlike TPR, there is not an increase in RPR as progressing from hinge zones of gentle folds to faulted hinge zones. However, this lack of increase is probably due to a grouping of rockfalls at the faulted-hinge zone site (see Methods section and caption of Table 2).

\section{Discussion}

Results indicate that fold geometries and fold-related discontinuities dramatically affect rockfall susceptibility. Our interpretation of rockfall susceptibility as related to different fold positions is shown in Fig. 2. The ranking is as follows (from 


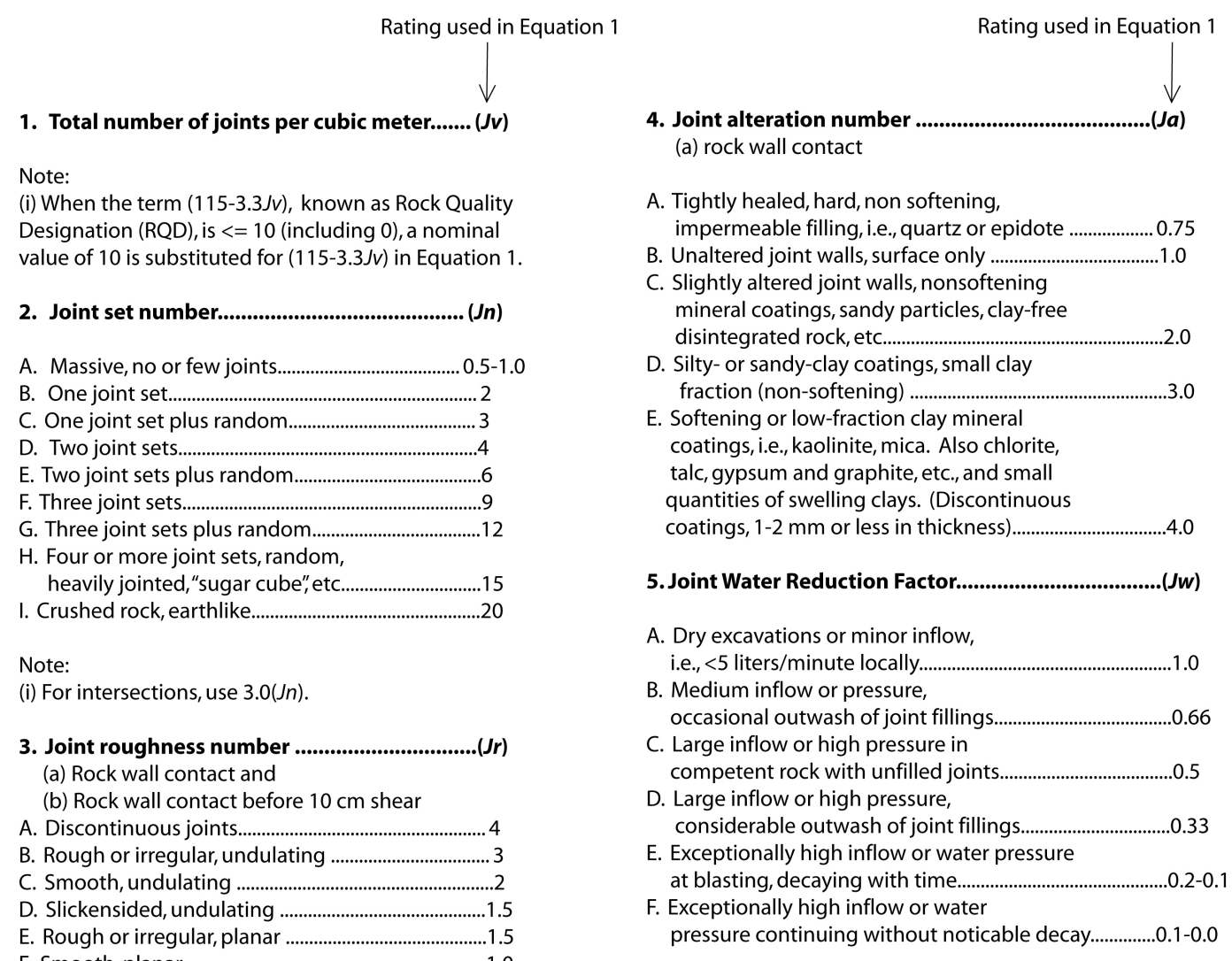

\section{Aperture......................................................................(AF)}

A. All joints tight.............................................................................

B. Most joints tight, a few open as much as $2 \mathrm{~cm}$..................... 2.5

C. Most joints tight, a few loose, open as much as $5 \mathrm{~cm}$.......5.0

D. Significantly (20 percent) open, as much as $10 \mathrm{~cm}$...........7.5

E. Greatly (60 percent) open, as much as $20 \mathrm{~cm}$.....................10.0

F. Gaping open, many joints open $>20 \mathrm{~cm}$.............................15.0

Notes:

(i) If perched or loose rocks are common, increase by one

(ii) If pervasive joints dip out of slope, increase by one

Fig. 4. Ratings used for Rock Mass Quality parameters given in Eq. (1). Note that we interpret "joint" to be synonymous with "discontinuity", which is used throughout the text. Ratings from Barton et al. (1974) and Harp and Noble (1993).

highest to lowest): very high susceptibility, faulted hinge zones and steeply dipping limbs; high susceptibility, hinge zones of gentle folds and moderately dipping limbs; moderate susceptibility, shallow-dipping limbs. Interpretations of rockfall paths and runout zones are also provided on Fig. 2, but since this paper concentrates on rockfall susceptibility, the reader should see Coe et al. (2005) for further details regarding paths and runout.

In general, our susceptibility ranking is based on the relative frequency of rockfall initiation as indicated by TPR (Table 2), which is in general agreement with patterns observed in RPR, Q, and discontinuity data (Table 2, Fig. 8). The exception to this statement is the susceptibility ranking of hinge zones of gentle folds (Gfhz, Fig. 2). TPR and Q data suggest that Gfhz should have the same ranking as shallow dipping limbs (Shdl), whereas the RPR data indicate that Gfhz should have the highest susceptibility ranking of all units (Table 2). A statistical t-test comparing the number of discontinuities $(J v)$ at sites in Gfhz and Shdl indicates that Gfhz has a significantly greater number, which could easily affect rockfall initiation and frequency. With our assignment of a high susceptibility ranking to Gfhz, we take a conservative approach (from a hazards perspective). The moderate disparity in hazard ranking between methods (i.e., rock mass quality assessment, talus production, and a historical rockfall record) suggests that none of the three methods is perfect, but that the 

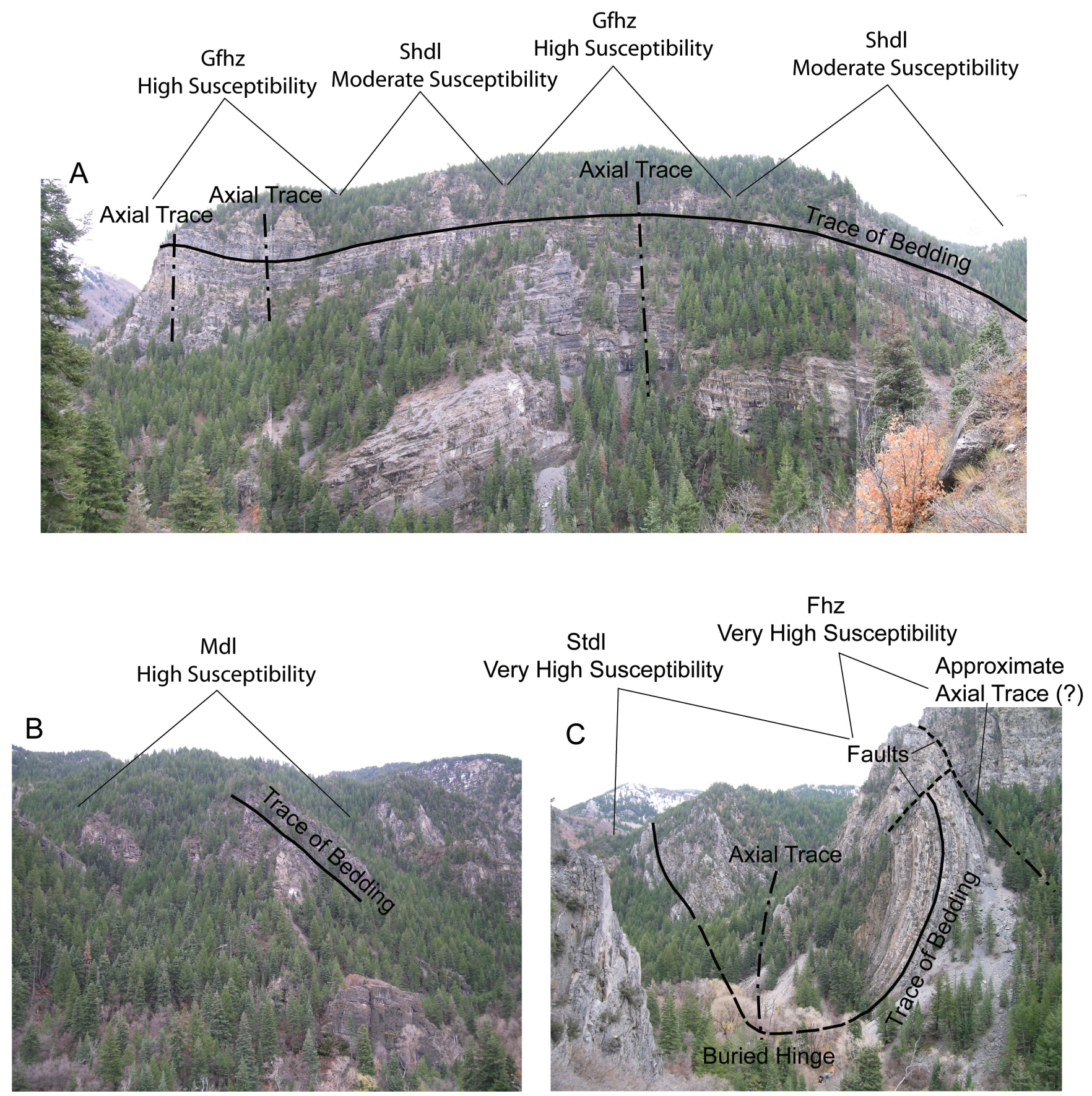

Fig. 5. Folds within the study area as progressing from east (A) to west (C). Solid black lines (dashed where buried) show form of folds. (A) Photo composite showing gentle folds in the eastern (left) and central (right) parts of the study area. Distance across the field of view is about $1500 \mathrm{~m}$. (B) Moderately dipping fold limb in the central part of the study area. Distance across the field of view is about $100 \mathrm{~m}$. (C) Close (buried hinge) and faulted folds in the western part of the study area. Distance across the field of view is about $400 \mathrm{~m}$.

combination of the three can provide strong support for accurate rockfall hazard interpretations in tectonically folded areas.

Our interpretation of the physical reasons for the observed patterns of rockfall activity, as well as our hazard interpretations, is as follows. On fold limbs, rockfall susceptibility increases as dip increases (Fig. 2 and Fig. 8). We attribute this correlation in large part to an increase in the surface smoothness of discontinuities (Fig. 8e) caused by shearing of bedding planes during flexural-slip folding (Ramsey, 1967, Figs. 7-55). Susceptibility increases with limb dip because the magnitude of shearing increases with limb dip (Ramsey, 

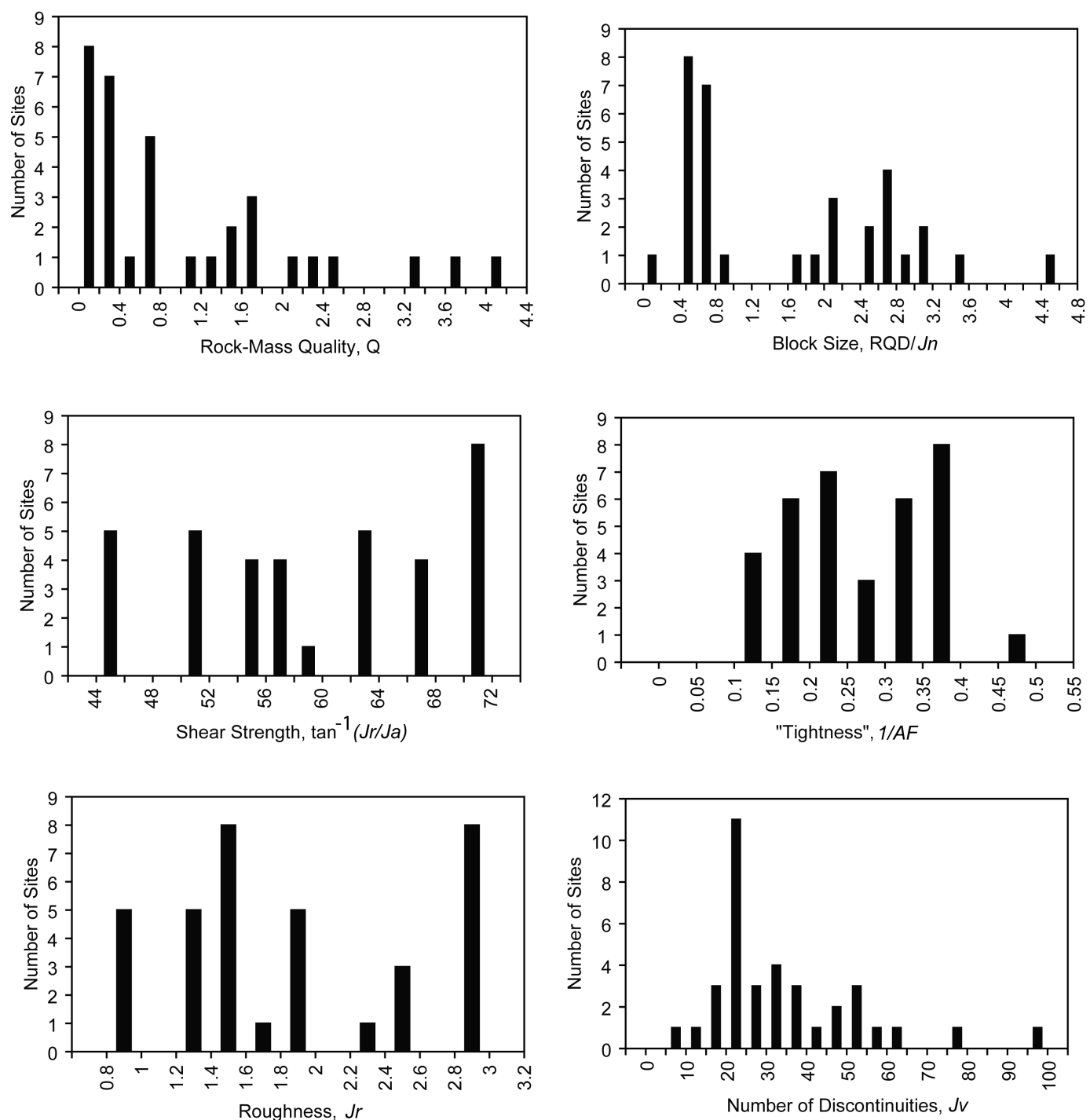

Fig. 6. Histograms showing Q and discontinuity data (see Eq. 1 in text) from the 36 Q measurement sites shown in Fig. 2. Histograms for Q, block size, and "tightness" have 2, 3, and 1, sites, respectively, with values greater than the maximum values shown on the $\mathrm{x}$-axis.

1967; Hutchinson, 1988). Shearing reduces the friction angles of discontinuities (Fig. 8c) by smoothing surface asperities (Norrish and Wyllie, 1996), thus making it easier for overlying rocks to slide. Hutchinson $(1988,1992)$ recognized the importance of flexural-slip in providing potential shear surfaces for all types of landslides. In 1992 (p. 1817), Hutchinson stated "A further, probably still more important, generator of pre-existing shears is flexural slip along bedding as a result of tectonic folding. The power and potential influence of this process tends to be underestimated".

Another important factor that increases susceptibility on steeply-dipping limbs is the observation that "rock tightness" $(1 / A F)$ decreases with increasing dip (Fig. 8d). Field observations indicate that this decrease in rock tightness is due to dilation of the rock mass (i.e., an increase in discontinuity aperture) and an increase in the occurrence, and steepness, of adverse dip as bedding dip increases. Larger apertures allow for rapid infiltration of water during wet periods, which can lead to local increases in water pressure and frost wedging during cold months.

Results suggest that susceptibility in hinge zones is greater than on adjacent limbs, and that susceptibility of hinge zones increases as fold curvature becomes tighter (Table 2). We primarily attribute higher susceptibility in hinge zones to an increase in the abundance of discontinuities $(J v)$, which provides an increased level of interconnectedness between discontinuities. The observed increase in $J v$ in hinge zones is consistent with most field studies and fold-fracture models (e.g., Price and Cosgrove, 1990; Bergbauer and Pollard, 2004) which indicate that extension, shear, and hybrid fractures can form in hinge zones during folding. 


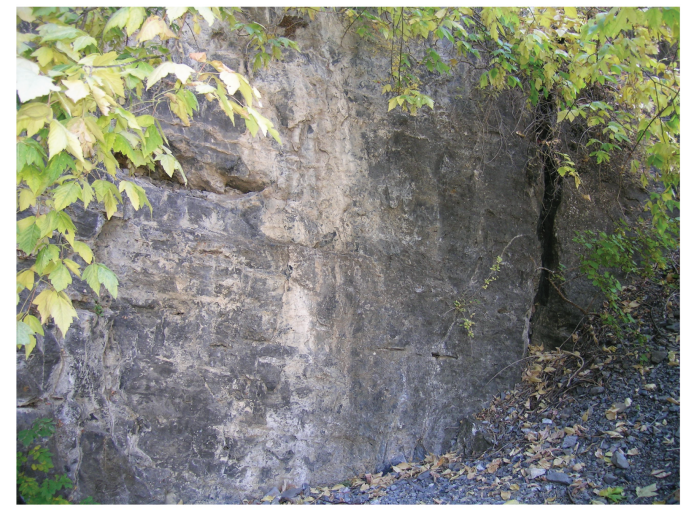

A

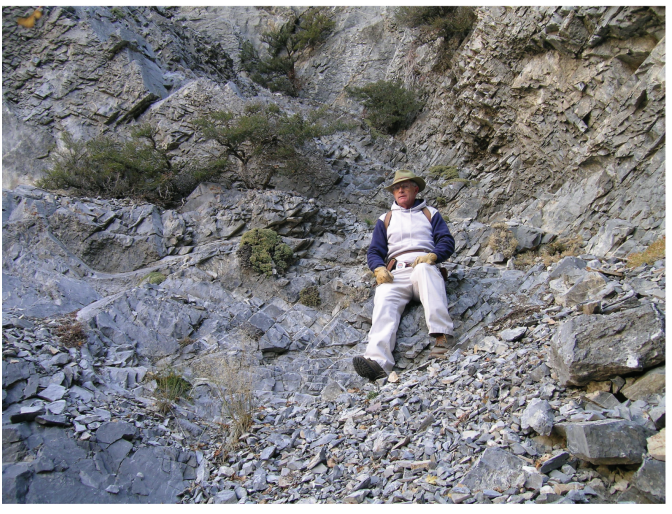

B

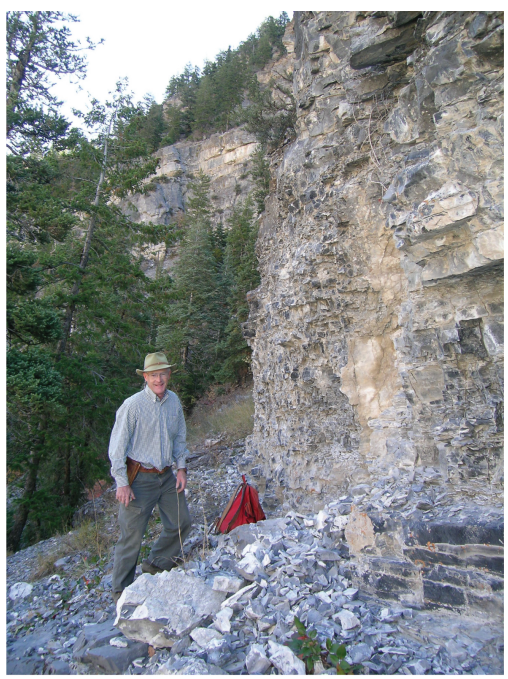

C

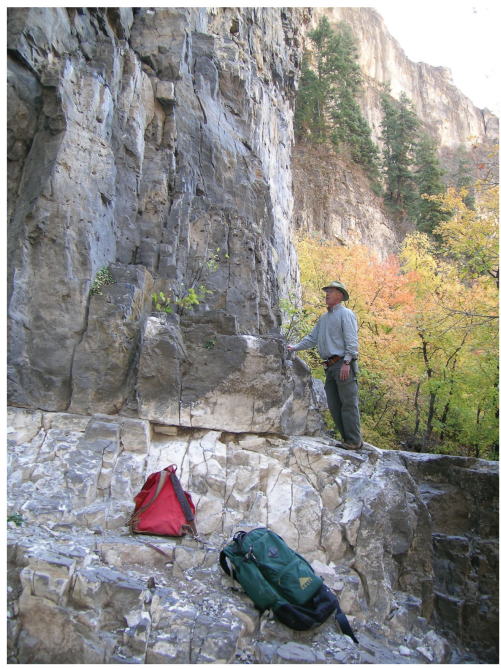

D

Fig. 7. Examples of Q measurement sites (see Fig. 2 for locations). (A) Site Q13 on a shallowly-dipping fold limb, width of exposure shown is about $3 \mathrm{~m}, \mathrm{Q}=4.10$, relative block size $=6.83$, estimated friction angle $=72^{\circ}$, rock tightness $=0.20$, roughness of discontinuities $=3$, number of discontinuities $=10$. (B) Site $\mathrm{Q} 23$ on a steeply-dipping fold limb, see geologist for scale, $\mathrm{Q}=0.19$, relative block size $=0.67$, estimated friction angle $=45^{\circ}$, rock tightness $=0.29$, roughness of discontinuities $=1$, number of discontinuities $=32$. (C) Site $\mathrm{Q} 8$ in the hinge zone of a gentle fold, see geologist for scale, $Q=0.14$, relative block size $=0.57$, estimated friction angle $=45^{\circ}$, rock tightness $=0.25$, roughness of discontinuities $=1$, number of discontinuities $=100$. (D) Site $\mathrm{Q} 12$ on a shallow-dipping limb, see geologist and backpacks for scale, $\mathrm{Q}=1.72$, relative block size $=2.75$, estimated friction angle $=68^{\circ}$, rock tightness $=0.25$, roughness of discontinuities $=2.5$, number of discontinuities $=24$.

We speculate that there is also a correlation between fold tightness and rockfall susceptibility of hinge zones based on data for the two end members of fold tightness (i.e., hinge zones of gentle folds and a faulted hinge zone of the apparent close fold). The TPR data for these two hinge-zone types clearly show that the faulted hinge zone has a much higher susceptibility than do the gentle hinge zones (Table 2). We are also confident that if the historical data from the faulted hinge were fully discriminated as individual falls, instead of grouped, the RPR for the faulted hinge would be higher than the RPR for the hinges of gentle folds. Our speculation is supported by studies of fractures in fold zones, which indicate that the number of fractures is typically highest where fold curvature is greatest (e.g., Lisle, 1994; Hennings et al., 2000; Cooke et al., 2000).

\section{Conclusions}

Results from this study in a tectonically folded, mountainous region of north-central Utah indicate that rockfall 

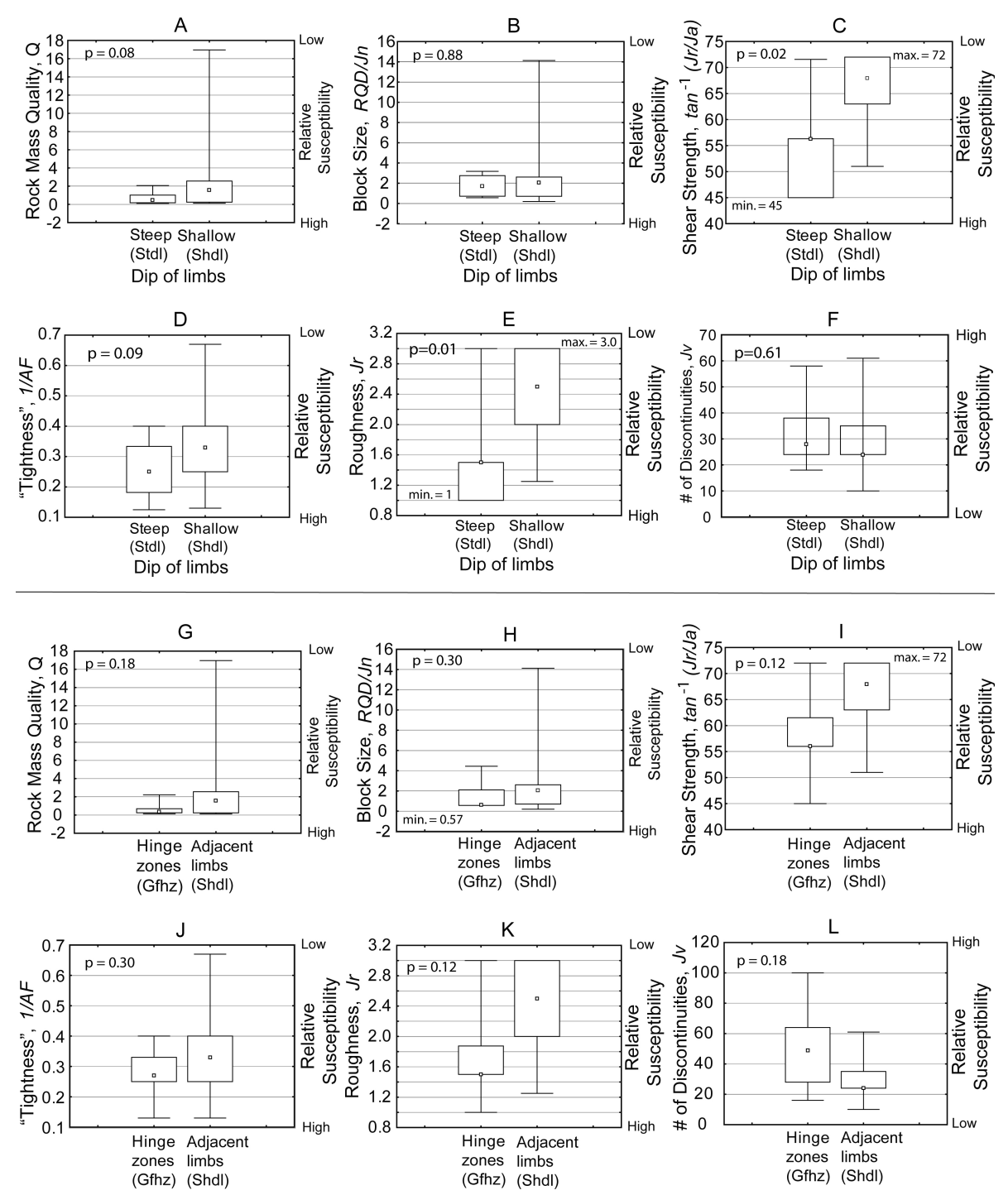

Median

$25 \%-75 \%$

I Min-Max

Fig. 8. Box and whisker plots of Q and discontinuity data from the study area. Upper half of diagram contains data from limbs; number of sites is 13 for steep limbs and 13 for shallow limbs; quantity of data from moderate limbs was insufficient (Fig. 2) for statistical analysis. Lower half of diagram contains data from the hinge zone of a gentle fold and adjacent, shallowly-dipping limbs; number of sites is 8 for hinge zones and 13 for adjacent limbs. $\mathrm{P}$ values shown are two-tailed values from the unpaired Mann-Whitney statistical analysis.

susceptibility systematically varies according the dip of fold limbs and curvature of fold hinge zones. On fold limbs, rockfall susceptibility increases as dip increases. Susceptibility is greater in fold hinge zones than on adjacent limbs, and increases as fold curvature becomes tighter. These conclusions, which are supported by rock-mass-quality measurements, historical rockfall activity, and long-term talus accumulation, suggest that investigators should incorporate fold position and fold geometry as important variables when conducting rockfall hazard assessments in folded terrane.

Our work was conducted in an area where fold axes were oriented nearly perpendicular to canyon walls, creating a situation where fold geometries are exposed in cross section by the canyon walls. Fold axes that are oriented differently with respect to topography, may produce different rockfall susceptibility results than this study. Additional studies of rockfall in tectonically folded terranes could be useful in understanding possible variations in susceptibility as a function of fold axis orientation and topographic slope. 

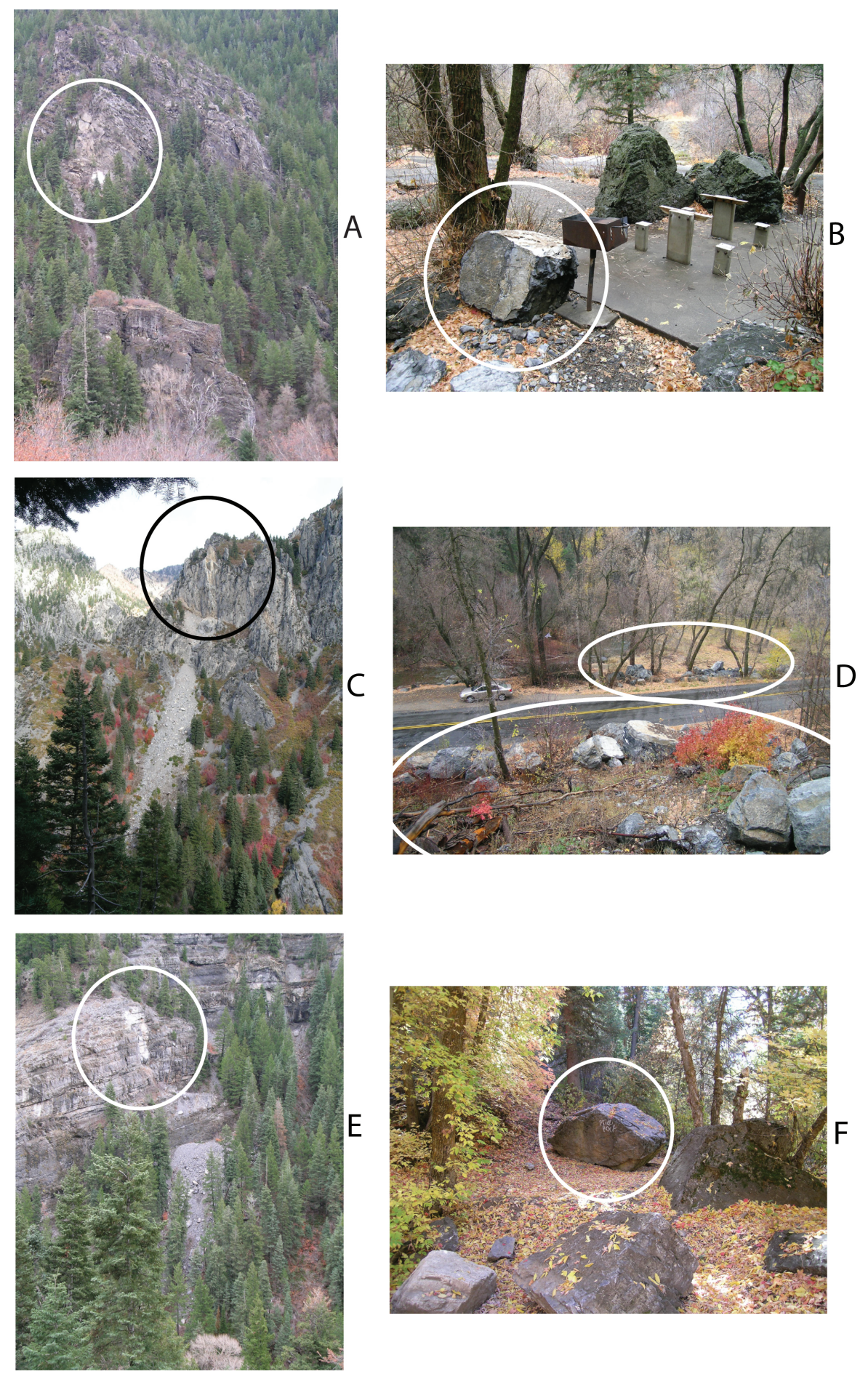

Fig. 9. Pairs of photographs showing source areas (circled at left) and rocks (circled at right) from recent rockfall events in and near the study area. (A), (B) Rockfall from moderately dipping fold limb (see Fig. 2 for location). Bedrock exposed in circle in (A) is about $20 \mathrm{~m}$ in height. Rock in circle in (B) is about $0.6 \mathrm{~m}$ in diameter. (C), (D) Rockfall from steeply dipping fold limb on the north side of American Fork Canyon. Bedrock exposure above fresh talus in (C) is about $50 \mathrm{~m}$ in height. See car for scale in (D). (E), (F) Rockfall from hinge zone of a gentle fold (see Fig. 2 for location). Bedrock exposed in circle in (E) is about $30 \mathrm{~m}$ in height. Maximum dimension of rock in circle in (F) is about $3.5 \mathrm{~m}$. 
Acknowledgements. This work was supported by the Uinta National Forest, Pleasant Grove District, Utah. We thank M. Jaboyedoff, D. Lidke, S. Martel, E. Nelson, A. Volkwein, and two anonymous reviewers, for their constructive, critical reviews of this paper.

Edited by: F. Guzzetti

Reviewed by: M. Jaboyedoff, A. Volkwein, and another referee

\section{References}

Allison, R. J. and Kimber, O. G.: Modelling failure mechanisms to explain rock slope change along the Isle of Purbeck coast, UK, Earth Surface Processes and Landforms, 23, 731-750, 1998.

Armstrong, R. L.: Sevier orogenic belt in Nevada and Utah, Geol. Soc. Amer. Bull., 79, 429-458, 1968.

Baker, A. A. and Crittenden Jr., M. D.: Geology of the Timpanogos Cave quadrangle, Utah, U.S. Geological Survey Geologic Quadrangle GQ-132, 1:24 000-scale, 1961.

Barton, N., Lien, R., and Lunde, J.: Engineering classification of rock masses for the design of tunnel support, Norwegian Geotechnical Institute, Oslo, Norway, 1974.

Bates, R. L. and Jackson, J. A.: Glossary of Geology (3rd edition), American Geological Institute, Alexandria Virginia, 1987.

Bergbauer, S. and Pollard, D. D.: A new conceptual fold-fracture model including prefolding joints, based on the Emigrant Gap anticline, Wyoming, Geol. Soc. Amer. Bull., 116, 294-307, 2004.

Coe, J. A., Harp, E. L., Tarr, A. C., and Michael, J. A.: Rockfall hazard assessment of Little Mill campground, American Fork Canyon, Uinta National Forest, Utah, U.S. Geological Survey Open-File Report 2005-1229, Reston, Virginia, http://pubs.usgs. gov/of/2005/1229/, 2005.

Cooke, M. L.: Predicting fracture localization in folded strata from mechanical stratigraphy and fold shape: case study of East Kaibab Monocline, Utah, Int. J. Rock Mechanics and Mining Sci., 34, 351, 1997.

Cooke, M. L., Mollema, P. N., Pollard, D. D., and Aydin, A.: Interlayer slip and joint localization in the East Kaibab Monocline, Utah: field evidence and results from numerical modeling, in: Forced Folds and Fractures, edited by: Cosgrove, J. W. and Ameen, M. S., The Geological Society of London, 23-49, 2000.

Deere, D. U. and Deere, D. W.: Rock Quality Designation (RQD) after twenty years, Contract Report GL-89-1, U.S. Army Engineer Waterways Experiment Station, Vicksburg, Mississippi, 1989.

Ehlers, T. A., Willet, S. D., Armstrong, P. A., and Chapman, D. S.: Exhumation of the central Wasatch Mountains, Utah: 2. Thermokinematic model of exhumation, erosion, and thermochronometer interpretation, J. Geophys. Res., 108(B3), 2173, doi:10.1029/2001JB001723, 2003.

Fleuty, M. J.: The description of folds, Geol. Assoc. Proc., 75, 461492, 1964.

Freeze, R. A. and Cherry, J. A.: Groundwater, Prentice-Hall, Inc., Englewood Cliffs, New Jersey, 1979.

Hales, T. C. and Roering, J. J.: Climate-controlled variations in scree production, Southern Alps, New Zealand, Geology, 33, 701-704, 2005.
Hantz, D., Vengeon, J. M., and Dussauge-Peisser, C.: An historical, geomechanical and probabilistic approach to rock-fall hazard assessment, Nat. Hazards Earth Syst. Sci., 3, 693-701, 2003, http://www.nat-hazards-earth-syst-sci.net/3/693/2003/.

Harp, E. L. and Noble, M. A.: An engineering rock classification to evaluate seismic rock-fall susceptibility and its application to the Wasatch Front, Bull. Assoc. Eng. Geologists, 30, 293-319, 1993.

Harp, E. L. and Jibson, R. W.: Anomalous concentrations of seismically triggered rock falls in Pacoima Canyon: are they caused by highly susceptible slopes or local amplification of seismic shaking, Bull. Seismological Soc. Amer., 92, 3180-3189, 2002.

Hencher, S. R.: The implications of joints and structures for slope stability, in: Slope Stability - geotechnical engineering and geomorphology, edited by: Anderson, M. G. and Richard, K. S., John Wiley and Sons, Chichester, 145-186, 1987.

Hennings, P. H., Olson, J. E., and Thompson, L. B.: Combining outcrop data and three-dimensional structural models to characterize fractured reservoirs, an example from Wyoming, Amer. Assoc. Petroleum Geologists Bull., 84, 830-849, 2000.

Hutchinson, J. N.: General report: Morphological and geotechnical parameters of landslides in relation to geology and hydrology: in: Landslides - Proceedings of the Fifth International Symposium on Landslides, edited by: Bonnard, C., Balkema, Rotterdam, 1, 3-35, 1988.

Hutchinson, J. N.: Landslide hazard assessment, in: Landslides - Proceedings of the Sixth International Symposium on Landslides, edited by: Bell, D. H., Balkema, Rotterdam, 3, 18051841, 1992.

Jaboyedoff, M., Baillifard, F., Bardou, E., and Girod, F.: The effect of weathering on alpine rock instability, Quart. J. Eng. Geol. Hydrogeol., 37, 95-103, 2004.

Lisle, R. J.: Detection of zones of abnormal strains in structures using Gaussian curvature analysis, Amer. Assoc. Petroleum Geologist Bull., 78, 1811-1819, 1994.

Mann, H. B. and Whitney, D. R.: On a test of whether one of 2 random variables is stochastically larger than the other, Ann. Math. Statist., 18, 50-60, 1947.

McNeil, B. E., Jasper, J. D., Luchsinger, D. A., and Rainsmeir, M. V.: Implementation and application of GIS at Timpanogos Cave National Monument, Utah, J. Cave and Karst Studies, 64(1), 3437, 2002.

Miller, D. J. and Dunne, T.: Topographic perturbations of regional stresses and consequent bedrock fracturing, J. Geophys. Res., 101, 25 523-25 536, 1996.

Norrish, N. I. and Wyllie, D. C.: Rock slope stability analysis, in: Landslides - investigation and mitigation: Transportation Research Board Special Publication 247, edited by: Turner, A. K. and Schuster, R. L., National Research Council, National Academy Press, Washington, D.C., 391-425, 1996.

Paulsen, T. and Marshak, S.: Charleston transverse zone, Wasatch Mountains, Utah: Structure of the Provo salient's northern margin, Sevier fold-thrust belt, Geol. Soc. Amer. Bull., 110, 512522, 1998.

Pierre, G. and Lahousse, P.: The role of groundwater in cliff instability: an example at Cape Blanc-Nez (Pas-de-Calais, France), Earth Surface Processes and Landforms, 31, 31-45, 2006.

Pillmore, C. L.: Geologic photogrammetry in the U.S. Geological Survey, Photogrammetric Engineering and Remote Sensing, 55, 
1185-1189, 1989.

Price, N. J. and Cosgrove, J. W.: Analysis of geological structures, Cambridge University Press, Cambridge, 1990.

Ramsey, J. G.: Folding and fracturing of rocks, McGraw-Hill Book Company, New York, 1967.

Selby, M. J.: Controls on the stability and inclinations of hillslopes formed on hard rock, Earth Surface Processes and Landforms, 7, 449-467, 1982.

Selby, M. J.: Hillslope materials and processes (2nd edition), Oxford University Press, New York, 1993.

Varnes, D. J.: Slope movement types and processes, in: Landslides: Analysis and Control, edited by: Schuster, R. L. and Krizek, R. J., Transportation Research Board Special Report 176, National Research Council, Washington, D.C., 11-33, 1978.
Weissel, J. K. and Seidl, M. A.: Influence of rock strength properties on escarpment retreat across passive continental margins, Geology, 25, 631-634, 1997.

Whalley, W. B.: Rockfalls, in: Slope Instability, edited by: Brunsden, D. and Prior, D. B., John Wiley and Sons, Chichester, 217 256, 1984.

Wieczorek, G. F. and Snyder, J. B.: Historical rock falls in Yosemite National Park, California, U.S. Geological Survey Open File Report 03-491, 2004.

Wilcoxon, F.: Individual comparisons by ranking methods, Biometrics Bull., 1, 80-83, 1945. 